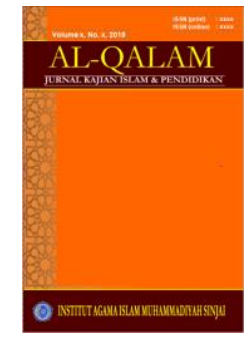

AL-QALAM

Jurnal Kajian Islam \& Pendidilkan

Volume 7, No. 1, 2015

ISSN (print) : 1858-4152

ISSN (online) : 2715-5684

Homepage : http://journal.al-qalam.iaims.ac.id

\title{
PERTIMBANGAN ETIKA AGAMA DALAM APLIKASI ILMU
}

Oleh: Suriyati ${ }^{*}$

$* * *$

\begin{abstract}
Abstrak
Kemajuan ilmu agaknya tidak selalu diiringi dengan kesadaran akan nilai-nilai kemanusiaan yang tinggi. Masyarakat di negara maju pun tidak luput dari persoalan yang ditimbulkan oleh kemajuan ilmu dan teknologi. Masyarakatnya cenderung bersifat materialistis, individualism, dan lebih longgar di dalam menerapkan nilai-nilai moral keagamaan. Pertimbangan "etika agama dalam aplikasi ilmu" perlu dipikirkan dan diusahakan untuk menata kehidupan lebih baik. Berdasarkan hal itu, maka dalam tulisan ini dirumuskan dua permasalahan yaitu: Bagaimana definisi etika, agama, dan ilmu?; dan Bagaimana pertimbangan etika agama dalam aplikasi ilmu?. Dalam hasil pembahasan dikemukakan bahwa Etika dalam Islam (bisa dikatakan) identik dengan ilmu akhlak, yakni ilmu tentang keutamaan-keutamaan dan bagaimana cara mendapatkannya agar manusia berhias dengannya; dan ilmu tentang hal yang hina dan bagaimana cara menjauhinya agar manusia terbebas daripadanya. Etika, dilain pihak, seringkali dianggap sama dengan akhlak.
\end{abstract}

Kata Kunci: Agama, Etika, Ilmu, Aplikasi Ilmu, Akhlak

\section{PENDAHULUAN}

Dewasa ini ilmu pengetahuan mengalami perkembangan yang amat pesat. Perkembangan tersebut melahirkan kemajuan teknologi yang sangat maju sehingga manusia dapat merasakan berbagai kemudahan dan kenikmatan hidup. Hanya saja kemajuan yang dimaksud tidak merata di berbagai belahan bumi sehingga kualitas hidup manusia pun tidak merata. Di satu sisi ada negara yang sangat maju, sedang di sisi lain ada negara yang sangat terbelakang. Kondisi yang lebih memprihatinkan lagi, negara maju kurang memperlihatkan kesungguhan untuk membantu negara terbelakang. Bahkan beberapa negara berkembang merasakan pahit getir penderitaan berkepanjangan dalam mengangkat harkat dan martabat

\footnotetext{
* Dosen STAI Muhammadiyah SInjai
} 


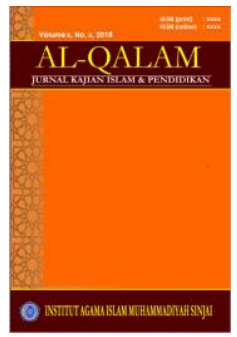

AL-QALAM

Jurnal Kajian Islam \& Pendidlikan

Volume 7, No. 1, 2015

ISSN (print) : 1858-4152

ISSN (online) : 2715-5684

Homepage : http://journal.al-qalam.iaims.ac.id

rakyatnya dari berbagai aspek kehidupan yang ditimbulkan oleh negara-negara maju terlebih dahulu meraih kemajuan melalui jalur imperialism dalam beragam bentuknya.

Kemajuan ilmu agaknya tidak selalu diiringi dengan kesadaran akan nilai-nilai kemanusiaan yang tinggi. Masyarakat di negara maju pun tidak luput dari persoalan yang ditimbulkan oleh kemajuan ilmu dan teknologi. Masyarakatnya cenderung bersifat materialistis, individualism, dan lebih longgar di dalam menerapkan nilai-nilai moral keagamaan. Ada benarnya ungkapan yang menyatakan bahwa "kendati pun ilmu dan teknologi mungkin menyumbang pada usaha perbaikan kualitas kehidupan manusia namun bukan pula sumber yang mewakili kemampuan apalagi kemutlakan berlakunya-sesuatu nilai'. Dominasi negara-negara maju terhadap negara-negara berkembang berlangsung terus hingga sekarang.

Meskipun disadari bahwa tidak semua yang datang dari barat itu baik, namun pengaruh budaya dari negara maju semakin sulit dielakkan. Dikatakan bahwa arus pengaruh globalisasi yang sedang melanda kemanusiaan di seantero jagad memancar terutama dari pusat yang kuat terhadap lingkaran yang lemah. Ilmu berkembang pesat di negara maju. Namun, seperti dikatakan Kuntowijoyo, hampir semua cabang ilmu pengetahuan yang berkembang di barat muncul dari pendekatan non agama, jika bukan anti agama. Hanya dirasakan oleh masyarakat di Barat saja, namun menjalar ke berbagai belahan bumi. ${ }^{1}$

Pertimbangan "etika agama dalam aplikasi ilmu" perlu dipikirkan dan diusahakan untuk menata kehidupan lebih baik. Ilmu-ilmu yang mampu mengangkat kualitas hidup manusia secara lahiriah perlu diintegrasikan dengan ilmu-ilmu yang membawa kepada kesejahteraan batin, melainkan akan membahas secara ringkas landasan untuk melakukan hal tersebut, terutama dari sudut pandang kitab suci sebagai pedoman hidup umat Islam, yaitu alQur'an.

Berdasarkan latar belakang di atas, maka dirumuskan beberapa masalah yang akan dibahas, yaitu: Bagaimana definisi etika, agama, dan ilmu?; dan Bagaimana pertimbangan etika agama dalam aplikasi ilmu?

${ }^{1}$ Said Agil Husain al-Munawar, Aktualisasi Nilai-nilai Qur'ani dalam Sistem Pendidikan Islam, (Cet. II; Ciputat: PT. Ciputat Press, 1426/2005), h. 74-75. 


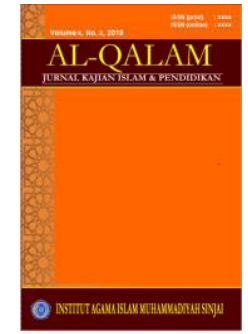

AL-QALAM

Jurnal Kajian Islam \& Pendidlikan

Volume 7, No. 1, 2015

ISSN (print) : 1858-4152

ISSN (online) : 2715-5684

Homepage : http://journal.al-qalam.iaims.ac.id

\section{PEMBAHASAN}

\section{A. Definisi Etika, Agama, dan Ilmu}

\section{Definisi Etika}

Secara etimologi, etika berasal dari bahasa Yunani yaitu ethikos, ethos (adat, kebiasaan, praktek). Sebagaimana digunakan Aristoteles istilah ini mencakup ide "karakter" dan "disposisi” (kecondongan). Kata moralis diperkenalkan ke dalam kosa kata filsafat oleh Cirero. Baginya kata ini ekuivalen dengan kata ethikos yang diangkat oleh Aristoteles. Kedua istilah itu menyiratkan hubungan dengan kegiatan praktis. $^{2}$

Sedangkan secara terminologi, beberapa ahli menguraikan definisi etika sebagai berikut:

\section{Mulyadhi Kartanegara:}

"Etika adalah filsafat moral atau ilmu akhlak, tidak lain daripada ilmu atau "Seni" hidup (the art of living) yang mengajarkan bagaimana cara hidup bahagia, atau bagaimana memperoleh kebahagiaan. Etika sebagai seni hidup etika sebagai pengobatan spiritual. ${ }^{3}$

\section{Ahmad Amin:}

"Etika adalah suatu ilmu yang menjelaskan arti baik dan buruk, menerangkan apa yang seharusnya dilakukan oleh sebagian manusia kepada lainnya, menyatakan tujuan yang harus dituju oleh manusia di dalam perbuatan mereka dan menunjukkan jalan untuk melakukan apa yang harus diperbuat. ${ }^{4}$

Poedjawiyatna mengatakan bahwa:

"Tindakan mungkin juga dinilai sebagai baik atau lawannya, ialah buruk. Kalau tindakan manusia dinilai atas baik-buruknya, tindakan itu seakan-akan keluar dari manusia, dilakukan dengan sadar atas pilihan, dengan satu perkataan: sengaja. Faktor kesengajaan ini mutlak untuk penilaian baik-buruk, yang disebut etis atau moral. ${ }^{\mathbf{5}}$

Sudarsono:

"Etika adalah ilmu yang membahas perbuatan baik dan perbuatan buruk manusia sejauh yang dapat dipahami oleh pikiran manusia. Etika disebut pula akhlak atau disebut pula moral. Apabila disebut "akhlaq" berasal dari bahasa arab. Apabila disebut "moral" berarti adat kebiasaan. ${ }^{6}$

\footnotetext{
${ }^{2}$ Lorens Bagus, Kamus Filsafat, (Cet. III; Jakarta: Gramedia, 1996), h. 217.

${ }^{3}$ Mulyadhi Kartanehara, Menembus Batas Waktu: Panorama Filsafat Islam, (Cet. II; Bandung: Mizan, 1426/2005). h. 67.

${ }^{4}$ Ahmad Amin, Etika (Ilmu Akhlak), (Cet. VII; Jakarta: Bulan Bintang, 1993), h. 3.

${ }^{5}$ Poedjawiyatna, Etika: Filsafat Tingkah Laku, (Cet. VIII; Jakarta: Rineka Cipta, 1996), h. 13-14.

${ }^{6}$ Sudarsono, Ilmu Filsafat, Suatu pengantar, (Cet. II; Jakarta: Rineka Cipta, 2001), h. 1.
} 


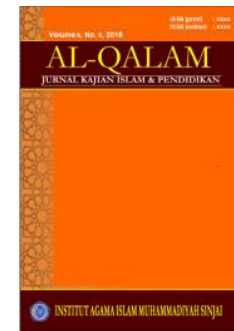

AL-QALAM

Jurnal Kajian Islam \& Pendidlikan

Volume 7, No. 1, 2015

ISSN (print) : 1858-4152

ISSN (online) : 2715-5684

Homepage : http://journal.al-qalam.iaims.ac.id

\section{Definisi Agama}

Secara etimologi, agama berasal dari kata Sanskrit. Ada yang berpendapat bahwa kata itu terdiri atas dua kata, a berarti tidak dan gam berarti pergi, jadi agama artinya tidak pergi; tetap ditempat; diwarisi turun temurun. Agama memang mempunyai sifat yang demikian. Pendapat lain mengatakan bahwa agama berarti teks atau kitab suci. Selanjutnya dikatakan bahwa gam berarti tuntunan. Agama juga mempunyai tuntunan, yaitu kitab suci. Istilah agama dalam bahasa asing bermacam-macam, antara lain: Religion, religio, religie, godsdienst, dan al-din. ${ }^{7}$

Sedangkan secara terminologi, beberapa ahli menguraikan definisi agama sebagai berikut:

J.G. Frazer:

"Agama adalah penyembahan kepada kekuatan yang lebih agung dari pada manusia, yang dianggap mengatur dan menguasai jalannya alam semesta. ${ }^{8}$

Mehdi Ha'iri Yazdi:

"Agama adalah kepercayaan kepada yang Mutlak atau kehendak Mutlak sebagai keperdulian tertinggi. ${ }^{9}$

Musthafa Abd Raziq:

"Agama terjemahan dari kata din yang berarti peraturan-peraturan yang terdiri atas kepercayaan-kepercayaan yang berhubungan dengan keadaan-keadaan suci. ${ }^{\mathbf{1 0}}$

A.M. Saefuddin:

"Agama merupakan kebutuhan paling esensial manusia yang bersifat universal. Karena itu, agama adalah kesadaran spiritual yang di dalamnya ada satu kenyataan di luar kenyataan yang tampak ini, yaitu bahwa manusia selalu mengharap belas kasihNya, bimbingan tangan-Nya, serta belaian-Nya, yang secara ontologism tidak diingkari, walaupun oleh manusia yang paling komunis sekalipun. ${ }^{11}$

Sutan Takdir Alisyahbana:

"Agama adalah suatu sistem kelakuan dan perhubungan yang berpokok pada perhubungan manusia dengan rahasia kekuasaan dan kegaiban yang tiada terhingga 1984), h. 72.

${ }^{7}$ Harun Nasution, Islam Ditinjau dari Berbagai Aspeknya, (Cet. I; Jakarta: UI Press, 1979), h. 9.

${ }^{8}$ Aslam Hady, Pengantar Filsafat Agama, (Cet. I; Bandung: Mizan, 1994), h. 6.

${ }^{9}$ Mehdi Ha’iri Yazdi, Ilmu Hudhuri, (Cet. I; Bandung: Mizan, 1994), h. 169.

10 Zainal Arifin Abbas, Perkembangan Pikiran terhadap Agama, (Cet. I; Jakarta: Pustaka Alhusna,

11 A.M. Saefuddin dkk., Desekularisasi Pemikiran landasan Islamisasi, (Cet. I; Bandung: Mizan, 1987), h. 47. 


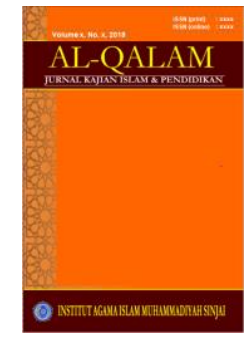

AL-QALAM

Jurnal Kajian Islam \& Pendidikan

Volume 7, No. 1, 2015

ISSN (print) : 1858-4152

ISSN (online) : 2715-5684

Homepage : http://journal.al-qalam.iaims.ac.id

luas, dalam dan mesranya di sekitarnya, dan dengan demikian memberi arti kepada hidupnya dan kepada alam semesta yang mengelilinya. ${ }^{12}$

Max Muller berpendapat bahwa definisi agama secara lengkap belum tercapai karena penelitian terhadap agama terus dilakukan dan para ahli agama masih menyelidiki asal usul agama. Jadi, definisi yang pasti dan lengkap tentang agama belum terealisir. ${ }^{13}$

Kendati Max Muller mengatakan bahwa definisi agama belum lengkap. Namun, dari definisi di atas beberapa unsur pokok dalam agama telah terungkap, yaitu masalah yang gaib, adanya hubungan baik dengan kekuatan gaib tersebut,, respon emosional dari manusia, baik respon dalam bentuk rasa takut, atau perasaan cinta, dan adanya yang suci, seperti kitab suci atau tempat suci.

\section{Definisi Ilmu}

'Ilm dari segi etimologi berarti kejelasan, karena itu segala yang terbentuk dari akar katanya mempunyai ciri kejelasan. Ilmu adalah pengetahuan yang jelas tentang sesuatu. ${ }^{\mathbf{1 4}}$

Menurut az-Zubardi, terjadi perdebatan panjang tentang istilah 'ilm sehingga sekelompok pakar berpendapat bahwa 'ilm tidak dapat didefinisikan karena kejelasannya. Ada pula yang mengatakannya karena sulitnya (mendefinisikannya). Demikian pula dengan pendapat-pendapat lain, dengan segala kelebihan dan kekurangannya, seperti disebutkan oleh Imam Abul hasan al-Yusi dalam kitab Qanun ul- 'Ulum. ${ }^{15}$

Al-Manawi dalam kitab at-Taiqif berkata, "ilmu adalah keyakinan kuat yang tetap sesuai dengan realita. Bisa juga berarti sifat yang membuat perbedaan tanpa kritik. Atau, ilmu adalah tercapainya bentuk sesuatu dalam akal. ${ }^{16}$

Imam Raghib al-Ashfahani dalam kitabnya, Mufradat al-Qur'an, berkata, "ilmu adalah mengetahui sesuatu sesuai dengan hakikatnya. Ia terbagi dua: pertama, mengetahui

\footnotetext{
12 Sutan Takdir Alisjahbana, Pemikiran Islam dalam Menghadapi Globalisasi, (Cet. I; Jakarta: Dian Rakyat, 1992), h. 48.

${ }^{13}$ Ronald Robertson, Agama alam Analisa dan Interpretasi Sosiologis, (Cet. I; Jakarta: Rajawali Press, 1993), h. 4.

${ }^{14}$ Muhammad Quraish Shihab, Wawasan al-Qur'an: Tafsir Maudhu'I Atas Pelbagai persoalan Umat, (Cet. VIII; Bandung: Mizan, 1419/1998), h. 434.

15 Yusuf Qardhawi, Al-'Aqlu wal-'ilmu fil-Qur'anil-Karim, diterjemahkan oleh Abdul Hayyie alKattani, Al-Qur'an berbicara tentang akal dan Ilmu pengetahuan, (Cet. I; Kairo: Maktabah Wahbah, 1416/1996) h. 89.

${ }^{16}$ Ibid., h. 88 .
} 


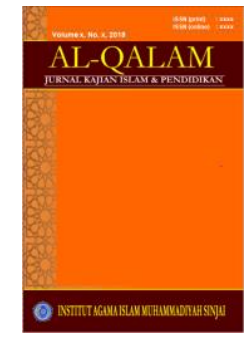

AL-QALAM

Jurnal Kajian Islam \& Pendidlikan

Volume 7, No. 1, 2015

ISSN (print) : 1858-4152

ISSN (online) : 2715-5684

Homepage : http://journal.al-qalam.iaims.ac.id

inti sesuatu itu (oleh ahli logika dinamakan thasawwur). Kedua, menghukum adanya sesuatu pada sesuatu yang ada, atau menafikan sesuatu yang tidak ada (oleh ahli logika dinamakan tashdiq, maksudnya mengetahui hubungan sesuatu dengan sesuatu). ${ }^{17}$

Raghib al-Ashfahani membagi ilmu dari sisi lain, yakni menjadi ilmu teoritis dan aplikatif. Ilmu teoritis berarti ilmu yang hanya membutuhkan pengetahuan tentangnya. Jika telah diketahui berarti telah sempurna, seperti ilmu tentang keberadaan dunia. Sedangkan, ilmu aplikatif adalah ilmu yang tidak sempurna tanpa dipraktekkan, seperti limu tentang ibadah, akhlak, dan sebagainya. ${ }^{18}$

Selanjutnya ar-Raghib menjelaskan, dari sudut pandang lainnya ilmu dapat pula dibagi menjadi dua bagian: Ilmu rasional dan doktrinal. Ilmu rasional adalah ilmu yang didapat dengan akal dan penelitian, sedangkan ilmu doktrinal merupakan ilmu yang didapat dengan pemberitaan wahyu. ${ }^{19}$

\section{B. Pertimbangan Etika Agama dalam Aplikasi Ilmu}

\section{Etika Agama}

Berbicara tentang etika dalam Islam tidak dapat lepas dari ilmu akhlak berbagai salah satu cabang ilmu pengetahuan agama Islam. Oleh karena itu etika dalam Islam (bisa dikatakan) identik dengan ilmu akhlak, yakni ilmu tentang keutamaan-keutamaan dan bagaimana cara mendapatkannya agar manusia berhias dengannya; dan ilmu tentang hal yang hina dan bagaimana cara menjauhinya agar manusia terbebas dari padanya. Etika, di lain pihak, seringkali dianggap sama dengan akhlak. Persamaannya memang ada, karena keduanya membahas masalah baik-buruknya tingkah laku manusia, akan tetapi akhlak lebih dekat dengan "kelakuan" atau "budi pekerti" 20 yang bersifat aplikatif, sedangkan etika lebih cenderung merupakan landasan filosofinya, yang membahas ilmu tentang apa yang baik dan apa yang buruk. ${ }^{21}$

Oleh karena itu, pada sebagian pandangan ethics yang dalam beberapa literatur Islam disebut sebagai falsafah akhlaqiyyah sering terabaikan dari perhatian sarjana, sejarawan, dan

\footnotetext{
17 Ibid.

${ }^{18}$ Ibid.

${ }^{19}$ Ibid.

${ }^{20}$ Anton M. Moeliono (Penyunting Penyelia), Kamus Besar Bahasa Indonesia, (Cet. I; Jakarta: Balai
} Pustaka, 1989), h. 15.

21 Ibid., h. 137. 


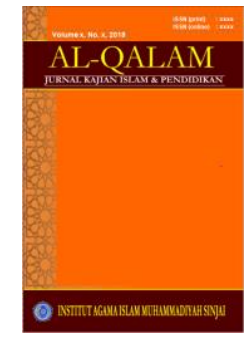

AL-QALAM

Jurnal Kajian Islam \& Pendidlikan

Volume 7, No. 1, 2015

ISSN (print) : 1858-4152

ISSN (online) : 2715-5684

Homepage : http://journal.al-qalam.iaims.ac.id

budayawan Islam. Pandangan semacam itu jelas didasari suatu keyakinan muslim, bahwa seluruh kandungan al-Qur'an merupakan etos muslim, sehingga seluruh disiplin ilmu dalam Islam bersumber dari padanya, yang oleh karenanya seluruh ilmu tersebut dianggap mengandung unsur-unsur akhlak. ${ }^{22}$

Namun pandangan lain menguraikan upaya perumusan etika dalam sejarah Islam dilakukan oleh beberapa pemikir dari berbagai cabang pemikiran-termasuk di dalamnya ulama hukum (syariat atau eksoteris), para teolog, para mistikus, dan para filosof. Berikut ini dikemukakan ciri-ciri etika dalam filsafat Islam: ${ }^{23}$

a. Islam berpihak pada teori tentang etika yang bersifat fitri. Dalam sebuah hadis Nabi Saw pun mengajarkan agar mengetahui baik buruknya sebuah perbuatan, kita menanyai hati nurani kita. ${ }^{24}$

b. Moralitas dalam Islam didasarkan kepada keadilan, yakni menempatkan segala sesuatu pada porsinya. ${ }^{25}$

c. Tindakan etis itu sekaligus dipercayai pada puncaknya akan menghasilkan kebahagiaan bagi pelakunya. ${ }^{26}$

d. Tindakan etis bersifat rasional.

Tujuan etika dalam pandangan filsafat adalah "ideal” yang sama bagi seluruh manusia di setiap waktu dan tempat, menentukan ukuran tingkah laku yang baik dan yang buruk sejauh yang dapat diketahui oleh akal manusia. Pola hidup yang diajarkan Islam bahwa seluruh kegiatan peribadatan, hidup, dan mati adalah semata-mata dipersembahkan kepada Allah, maka tujuan terakhir dari segala tingkah laku manusia menurut pandangan etika Islam adalah keridhaan Allah. ${ }^{27}$

\section{Aplikasi Ilmu}

${ }^{22}$ Suparman Syukur, Etika Religius, (Cet. I; Yogyakarta: Pustaka Pelajar, 2004), h. 3.

${ }^{23}$ M. Amin Abdullah, The Idea of Universality of Ethical Norms in Ghazali and kant, diterjemahkan oleh Hamzah Antara al-Ghazali dan Kant: Filsafat Etika Islam, (Cet. II; Bandung: Mizan, 2002), h. 18.

${ }^{24}$ Lihat al-Qur'an (Q.S. Al-Syam/91: 8-9).

25 Nabi Saw. Pun diketahui secara luas mengajarkan bahwa "urusan yang terbaik adalah Pertengahannya".

${ }^{26}$ Lihat al-Qur'an (Q.S. Lukman/31: 5, al-Baqarah/2: 58, al-A'raf/7: 16).

${ }^{27}$ Op. Cit., h. 4. 


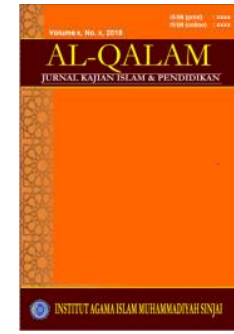

AL-QALAM

Jurnal Kajian Islam \& Pendidlikan

Volume 7, No. 1, 2015

ISSN (print) : 1858-4152

ISSN (online) : 2715-5684

Homepage : http://journal.al-qalam.iaims.ac.id

Aplikasi ilmu-ilmu apa yang dianjurkan Islam, telah merupakan pokok penting yang mendasar sejak hari-hari pertama Islam; apakah ada bentuk ilmu khusus yang harus dicari? Sebagian ulama besar Islam hanya memasukkan cabang-cabang ilmu yang secara langsung berhubungan dengan agama. Sedangkan tipe-tipe ilmu lain, mereka menyerahkan kepada masyarakat untuk menentukan ilmu mana yang paling esensial untuk memelihara dan menyejahterahkan diri mereka. Hadis "Mencari ilmu itu wajib bagi setiap muslim" telah melahirkan berbagai pembahasan, seperti ilmu apa yang harus dicari oleh seorang muslim. ${ }^{\mathbf{2 8}}$

Selanjutnya dapat dicatat bahwa Islam mengutamakan baik ilmu rasional maupun ilmu empiris. Tiada dogma, bagaimanapun keramat dan tuanya, dapat diterima dalam “ Islam dan bagi umat Islam, kecuali jika ia tahan uji rasio. Berulangkali al-Qur'an menantang kaum penganut kepercayaan yang palsu "untuk menunjukkan buktu-bukti tentang kebenarannya.,29

Al-Qur'an menganggap begitu pentingnya bukti dan kesahihan, sehingga menasihatkan orang-orang yang beriman agar tidak menerima sesuatu yang berada di luar pengetahuan mereka. Ayat sucinya yang berbunyi, “Janganlah menuruti sesuatu yang engkau tidak tahu apa-apa tentangnya. Sesungguhnya, telinga, mata, dan akal harus bertanggung jawab untuk itu.",30

\section{a. Objek ilmu}

Objek ilmu menurut ilmuwan muslim mencakup alam materi dan nonmateri. Tentu ada tata cara dan sarana yang harus digunakan untuk meraih pengetahuan tentang hal tersebut:

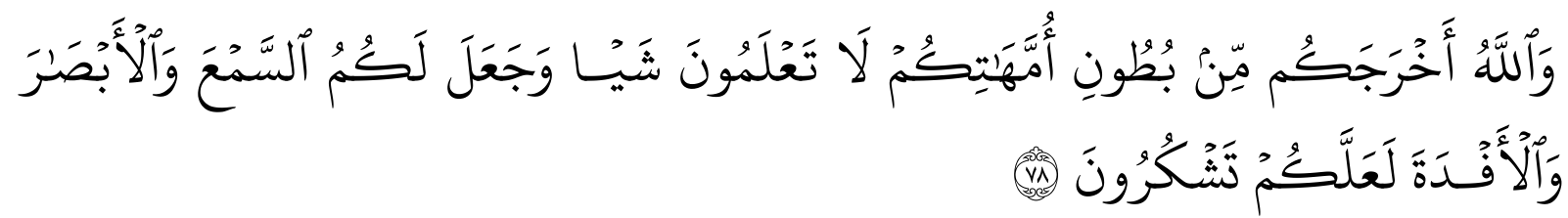

Terjemahnya:

Dan Allah mengeluarkan kamu dari perut ibumu dalam keadaan tidak mengetahui sesuatupun, dan Dia memberi kamu pendengaran, penglihatan dan hati, agar kamu bersyukur." (Q.S. Al-Nahl/16: 78). ${ }^{31}$

${ }^{28}$ Ghusyani. Mahdi, The Holy Quran and the Sciences of Nature, diterjemahkan oleh Agus Effendi, Filsafat Sains Menurut Al-Qur'an, (Cet. X; Bandung: Mizan, 1419/1998), h. 3.

${ }^{29}$ C. A. Qadir, Phylosophy and Science in the Islamic World, diterjemahkan oleh Hasan Basri, Filsafat dan Ilmu Pengetahuan dalam Islam, (tc; Jakarta: Yayasan Obor Indonesia, 1998), h. 17.

${ }^{30}$ Ibid.
${ }^{31}$ Departemen Agama RI, Op. Cit., h. 413. 


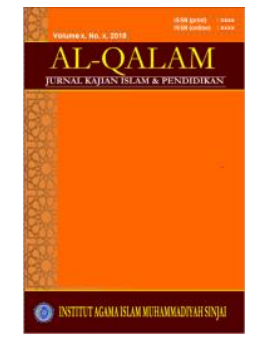

AL-QALAM

Jurnal Kajian Islam \& Pendidlikan

Volume 7, No. 1, 2015

ISSN (print) : 1858-4152

ISSN (online) : 2715-5684

Homepage : http://journal.al-qalam.iaims.ac.id

Ayat ini mengisyaratkan penggunaan empat sarana yaitu: Pendengaran, mata (penglihatan) dan akal, serta hati. Trial and error (coba-coba), pengamatan, percobaan, dan tes-tes kemungkinan (probability) merupakan cara-cara yang digunakan ilmuwan untuk meraih pengetahuan. Hal itu disinggung juga oleh al-Qur'an, seperti dalam ayat-ayat yang memerintahkan manusia untuk berfikir tentang alam raya, melakukan perjalanan, dan sebagainya, kendatipun hanya berkaitan dengan upaya manusia alam materi. ${ }^{32}$

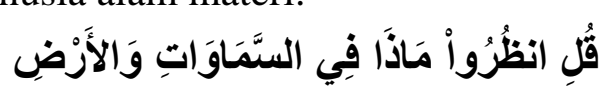

Terjemahnya:

Katakanlah: "Perhatikanlah apa yang ada di langit dan di bumi." (Q.S. Yunus/10: 101). ${ }^{33}$

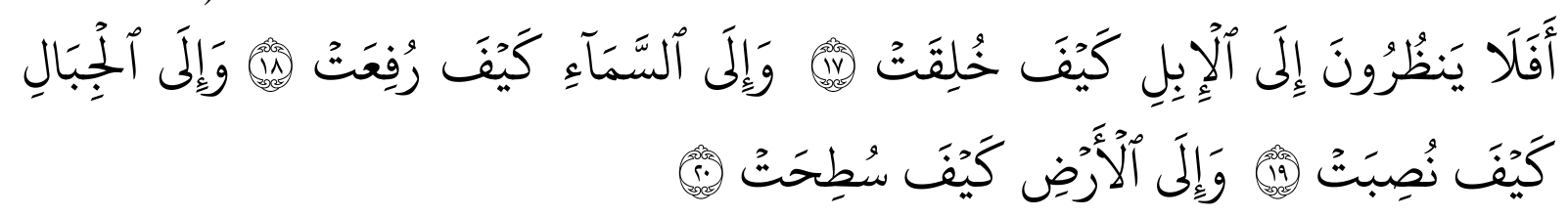

Terjemahnya:

Maka apakah mereka tidak memperhatikan unta bagaimana dia diciptakan,. Dan langit, bagaimana ia ditinggikan?. Dan gunung-gunung bagaimana ia ditegakkan?. Dan bumi bagaimana ia dihamparkan? (Q.S. al-Ghasyiyah/88: 17-20). ${ }^{34}$

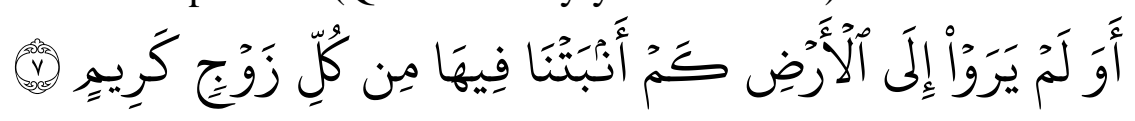

Terjemahnya:

Dan apakah mereka tidak memperhatikan bumi, berapakah banyaknya Kami tumbuhkan di bumi itu pelbagai macam tumbuh-tumbuhan yang baik? (Q.S. AlSyu'araa'/26: 7). ${ }^{35}$

Di samping mata, telinga, dan fikiran sebagai sarana meraih pengetahuan, al-Qur'an pun menggarisbawahi pentingnya peranan kesucian hati.

Wahyu dianugrahkan atas kehendak Allah dan berdasarkan kebijaksanaan-Nya tanpa usaha dan campur tangan manusia. Sementara firasat, intiusi, dan semacamnya, dapat diraih melalui penyucian hati. Dari sini para ilmuwan muslim menekankan pentingnya tazkiyah an-

\footnotetext{
${ }^{32}$ Muhammad Qurais Shihab, Op. Cit., h. 473.

${ }^{33}$ Ibid., h. 322.

${ }^{34}$ Ibid., h. 1055.

${ }^{35}$ Ibid., h. 572.
} 


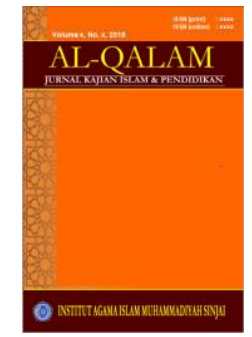

AL-QALAM

Jurnal Kajian Islam \& Pendidikan

Volume 7, No. 1, 2015

ISSN (print) : 1858-4152

ISSN (online) : 2715-5684

Homepage : http://journal.al-qalam.iaims.ac.id

nafs (penyucian jiwa) guna memperoleh hidayat (petunjuk/pengajaran Allah), karena mereka sadar terhadap kebenaran firman Allah:

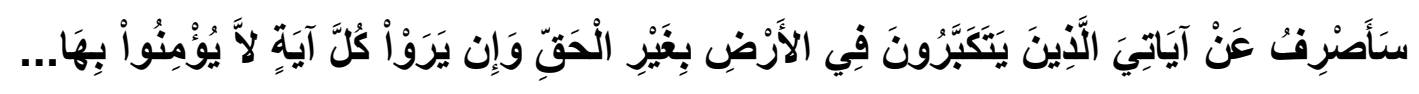

Terjemahnya:

Aku akan memalingkan orang-orang yang menyombongkan dirinya di muka bumi tanpa alasan yang benar dari tanda-tanda kekuasaan-Ku. Mereka jika melihat tiap-tiap ayat $(\mathrm{Ku}), \ldots\left(\mathrm{Q} . \mathrm{S}\right.$. Al-A'raf/7: 146). ${ }^{36}$

\section{b. Kategori Ilmu}

Dalam khazanah Islam, terdapat dua kategori ilmu pengetahuan: Ilmu-ilmu umum dan ilmu-ilmu agama. Adanya ilmu-ilmu umum dipahami dari surat Fathir/35:27-28, dan adanya ilmu-ilmu agama dari surat at-Taubah/9:122.

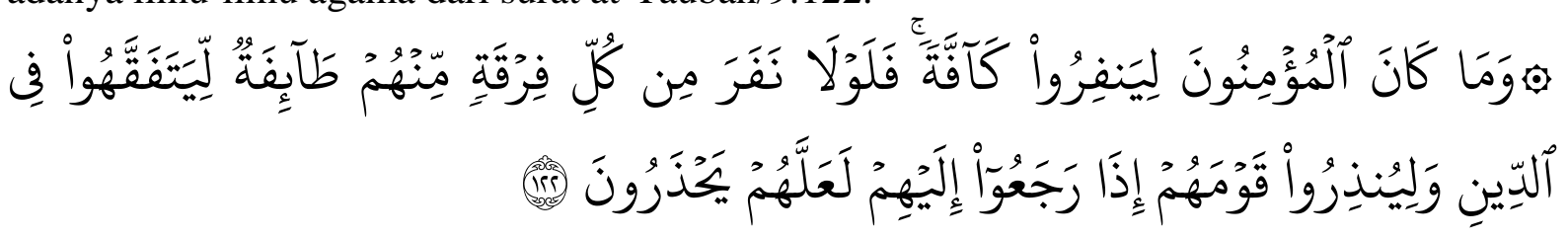

Terjemahnya:

Tidakkah kamu melihat bahwasanya Allah menurunkan hujan dari langit lalu Kami hasilkan dengan hujan itu buah-buahan yang beraneka macam jenisnya. Dan di antara gunung-gunung itu ada garis-garis putih dan merah yang beraneka macam warnanya dan ada (pula) yang hitam pekat." (Q.S. Fathir/35: 27). ${ }^{37}$

Di dalam ayat ini, Tuhan meminta manusia agar memperhatikan bagaimana hujan turun dari langit. Hal ini minimal bisa membuahkan pengembangan ilmu-ilmu meteorology. Pengamatan terhadap hujan yang menumbuhkan aneka ragam tumbuh-tumbuhan paling kurang dapat memicu berkembangnya ilmu-ilmu biologi dan kimia. Manusia juga diminta untuk memperhatikan gunung-gunung, menyangkut struktur dan kelakuannya. Ini bisa menjadi cikal-bakal pengembangan ilmu-ilmu geologi dan fisika. Ayat tersebut, dengan demikian, menghendaki pengembangan kelima cabang ilmu alam.

Dalam ayat berikutnya:

\footnotetext{
36 Ibid., h. 244.

${ }^{37}$ Departemen Agama RI, Op. Cit., h. 699.
} 


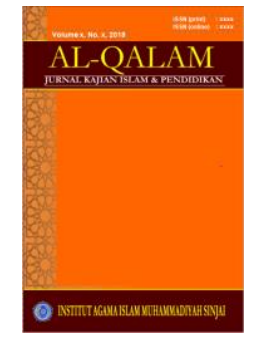

AL-QALAM

Jurnal Kajian Islam \& Pendidlikan

Volume 7, No. 1, 2015

ISSN (print) : 1858-4152

ISSN (online) : 2715-5684

Homepage : http://journal.al-qalam.iaims.ac.id

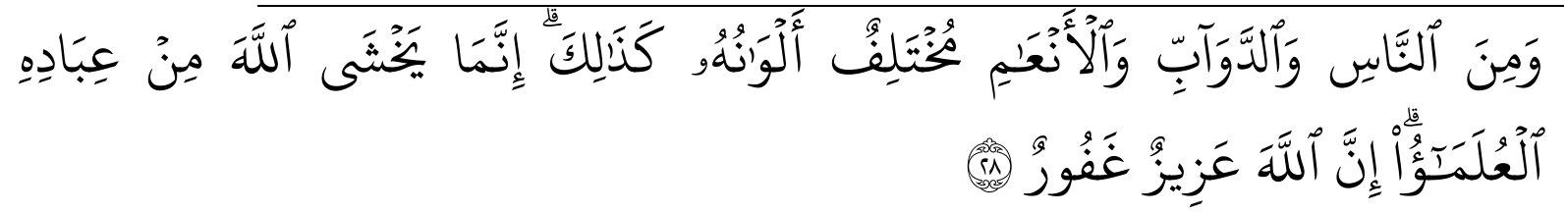

Terjemahnya:

Dan demikian (pula) di antara manusia, binatang-binatang melata dan binatangbinatang ternak ada yang bermacam-macam warnanya (dan jenisnya). Sesungguhnya yang takut kepada Allah di antara hamba-hamba-Nya, hanyalah ulama. Sesungguhnya Allah Maha perkasa lagi Maha hPengampun." (Q.S. Fathir/35: 28). ${ }^{38}$

Dalam ayat ini, Allah menyuruh manusia agar mengamati dirinya sendiri, hewan, dan ternak, yang beragam jenisnya. Bila pengamatan dilakukan, di samping akan mengembangkan ilmu-ilmu alam di atas, juga akan memajukan ilmu-ilmu sosial, termasuk ilmu ekonomi. Pengamatan terhadap manusia tentu akan melahirkan ilmu-ilmu budaya (humaniora). Jadi, ayat tersebut jelas menghendaki pengembangan ilmu-ilmu sosial dan humaniora.

Di pihak lain, dalam surah at-Taubah/9:122

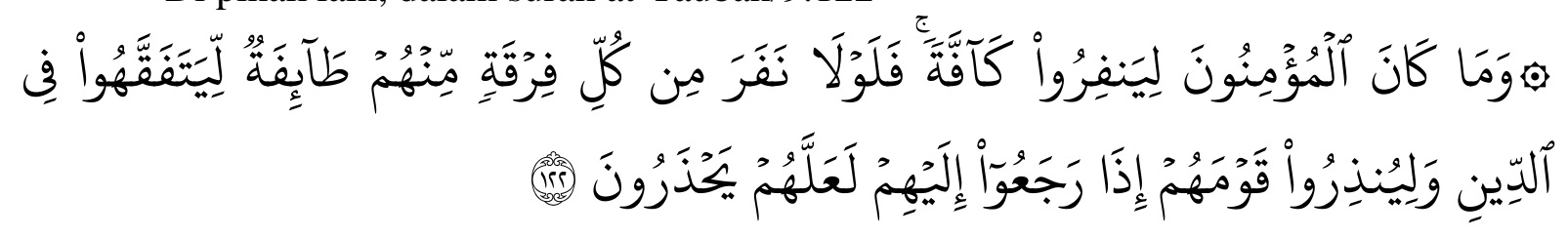

Terjemahnya:

Tidak sepatutnya bagi orang-orang yang mu'min itu pergi semuanya (ke medan perang). Mengapa tidak pergi dari tiap-tiap golongan di antara mereka beberapa orang untuk memperdalam pengetahuan mereka tentang agama dan untuk memberi peringatan kepada kaumnya apabila mereka telah kembali kepadanya, supaya mereka itu dapat menjaga dirinya." (Q.S. at-Taubah/9: 122). ${ }^{39}$

Allah mencela sikap yang selalu mengejar dunia saja. Dalam setiap golongan, Allah menghendaki adanya sekelompok orang yang mendalami agama, menasehati dan memajukan masyarakat.

Pengembangan kedua golongan besar ini harus proporsional. Memang, fungsi ilmuilmu umum bagi kemajuan di dunia, tidak diragukan. Tetapi, hendaknya perlu disadari bahwa ilmu-ilmu agama ikut berperan dalam membangun kehidupan dunia. Sebab, jika ilmu-ilmu umum membangun ketahanan fisik, maka ilmu-ilmu agama membekali pelaku pembangunan

\footnotetext{
${ }^{38}$ Ibid., h. 700.

${ }^{39}$ Ibid., h. 301.
} 


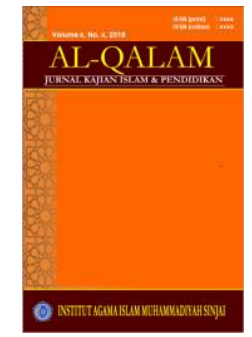

AL-QALAM

Jurnal Kajian Islam \& Pendidlikan

Volume 7, No. 1, 2015

ISSN (print) : 1858-4152

ISSN (online) : 2715-5684

Homepage : http://journal.al-qalam.iaims.ac.id

dengan ketahanan mental dan moral yang sangat penting bagi kesuksesan pembangunan.

Dengan demikian kedua jenis ilmu tersebut mesti dipelajari dan diperankan secara seimbang.

Kedua ilmuwan di bidangnya masing-masing hendaklah terlibat secara penuh. ${ }^{\mathbf{4 0}}$

Dari uraian di atas dapat disimpulkan bahwa ilmu yang diisyaratkan al-Qur'an dalam banyak hal, meliputi segala pengetahuan yang bisa menyingkap hakikat segala sesuatu serta dapat menghilangkan kabut kebodohan dan keraguan dari akal manusia. Obyeknya dapat berupa alam atau pun manusia, wujud maupun gaib. Demikian pula metode pengetahuannya, bisa berupa indra dan empiris ataupun akal.

\section{KESIMPULAN}

Dari berbagai uraian pada bab sebelumnya, maka dapat dikemukakan beberapa kesimpulan sebagai berikut:

1. Etika adalah filsafat moral atau ilmu akhlak, tidak lain dari pada ilmu atau "seni" hidup (the art of living) yang mengajarkan bagaimana cara hidup bahagia, atau bagaimana memperoleh kebahagiaan. Etika sebagai seni hidup etika sebagai pengobatan spiritual.

2. Agama merupakan kebutuhan paling esensial manusia yang bersifat universal. Karena itu, agama adalah kesadaran spiritual yang di dalamnya ada satu kenyataan yang tampak ini, yaitu bahwa manusia selalu mengharap belas kasih-Nya, bimbingan tangan-Nya, serta belaian-Nya, yang secara ontologism tidak diingkari, walaupun oleh manusia yang paling komunis sekalipun.

3. 'Ilm dari segi etimologi berarti kejelasan, karena itu segala yang terbentuk dari akar katanya mempunyai ciri kejelasan. Ilmu adalah pengetahuan yang jelas tentang sesuatu.

4. Etika dalam Islam (bisa dikatakan) identik dengan ilmu akhlak, yakni ilmu tentang keutamaan-keutamaan dan bagaimana cara mendapatkannya agar manusia berhias dengannya; dan ilmu tentang hal yang hina dan bagaimana cara menjauhinya agar manusia terbebas daripadanya. Etika, di lain pihak, seringkali dianggap sama dengan akhlak.

$$
* * *
$$

${ }^{40}$ Salman Harun, Mutiara al-Qur'an, Aktualisasi Pesan Al-Qur'an dalam Kehidupan, (Cet. I: Jakarta: Logos Wacana Ilmu, 1999), h. 87-89. 
Jurnal Kajian Islam \& Pendidikan

Volume 7, No. 1, 2015

ISSN (print) : 1858-4152

ISSN (online) : 2715-5684

Homepage : http://journal.al-qalam.iaims.ac.id 


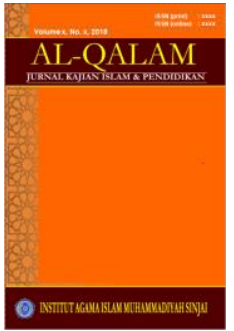

AL-QALAM

Jurnal Kajian Islam \& Pendidilkan

Volume 7, No. 1, 2015

ISSN (print) : 1858-4152

ISSN (online) : 2715-5684

Homepage : http://journal.al-qalam.iaims.ac.id

\section{DAFTAR PUSTAKA}

Abbas, Zainal Arifin, Perkembangan pikiran terhadapa Agama, Cet. I; Jakarta: Pustaka Alhusna, 1984.

Abdullah, M. Amin, The Idea of Universality of Ethical Norms in Ghazali and Kant, diterjemahkan oleh Hamzah, Antara al-Ghazali dan Kant: Filsafat Etika Islam, Cet.. II; Bandung: Mizan 1423/2002.

Alisjahbana, Sutan Takdir, Pemikiran Islam dalam menghadapi Globalisasi, Cet. I; Jakarta: Dian Rakyat, 1992.

Al-Munawwar, Said Agil Husain, Aktualisasi Nilai-nilai Qur'ani dalam Sistem Pendidikan Islam, Cet. II; Ciputat, PT. Ciputat Press, 1426/2005.

Amin, Ahmad, Etika (ilmu akhlak), Cet. VII; Jakarta: Bulan Bintang, 1993.

Hady, Aslam, Pengantar Filsafat Agama, Cet. I; Bandung: Mizan, 1994.

Harun, Salman, Mutiara al-Qur'an, Aktualisasi Pesan Al-Qur'an dalam kehidupan, Cet. I; Jakarta: Logos Wacana Ilmu, 1999.

Kartanegara, Mulyadhi, Menembus Batas Waktu: Panorama Filsafat Islam, Cet. II; Bandung: Mizan, 1426/2005.

Mahdi, Ghulsyani, The Holy Quran and the Sciences of Nature, diterjemahkan oleh Agus Effendi, Filsafat Sains Menurut Al-Qur'an, Cet. X; Bandung: Mizan, 1419/1998.

Moeliono, Anton M, (Penyunting Penyelia), Kamus Besar Bahasa Indonesia, Cet. I; Jakarta: Balai Pustaka, 1989.

Nasution, Harun, Islam Ditinjau dari berbagai Aspeknya. Cet. I; Jakarta: UI Press,1979.

Poedjawiyatna, Etika Filsafat Tingkah Laku. Cet. VIII; Jakarta: Rineka Cipta, 1990.

Qadir, C. A., Phylosophy and Science in the Islamic World, diterjemahkan oleh Hasan Basri, Filsafat dan Ilmu Pengetahuan dalam Islam, tc; Jakarta: Yayasan Obor Indonesia, 1988.

Qardhawi, Yusuf, Al-'Aqlu wa-'Ilmu fil-Qur'anil Karim, diterjemahkan oleh Abdul Hayyie al-Kattani, Al-Qur'an berbicara tentang akal dan Ilmu pengetahuan, Cet. I; Kairo: Maktabah Wahbah, 1416/1996.

Robertson, Ronald, Agama dalam Analisa dan Interpretasi Sosiologis, Cet. I; Jakarta: Rajawali Pers, 1993. 


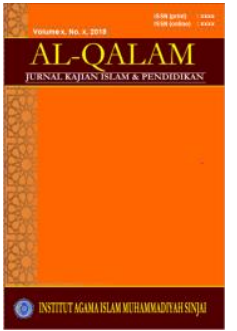

AL-QALAM

Jurnal Kajian Islam \& Pendidikan

Volume 7, No. 1, 2015

ISSN (print) : 1858-4152

ISSN (online) : 2715-5684

Homepage : http://journal.al-qalam.iaims.ac.id

Saefuddin, A.M., dkk., Desekularisasi Pemikiran Landasan Islamisasi, Cet. I; Bandung: Mizan, 1987.

Shihab, Muhammad Quraish, Wawasan al-Qur'an: Tafsir Maudhu'I Atas Pelbagai Persoalan Umat, Cet. VIII; Bandung: Mizan, 1419/1998.

Sudarsono, Ilmu Filsafat, Suatu Pengantar, Cet. II; Jakarta: Rineka Cipta, 2001. 